\title{
PENERAPAN FORMULA FENG SHUI DENGAN PERTIMBANGAN FORM DALAM BANGUNAN DAN LINGKUNGAN BINAAN
}

\author{
Dewi Mariana*
}

\begin{abstract}
Feng Shui was an ancient Chinese knowledge which had been applied as a man-made design approach and physical environment arrangement until recent time. However, lots of people forgot, did not realize or even did not know that Feng Shui does was not only emphasized formulas but also the forms. Problems were noticed in Feng Shui practitioners' image, e.i. architects and contractors in majority, and most of project owners had had a negative priori : when a Feng Shui practitioner was involved, the design would be a mess, became weird ugly looking, and they could be confused in the process. This paper showed four commonly used methods which were used by Feng Shui practitioners, which practically emphasized the applications of formula and forgot the form, but in the other hand, basic Feng Shui theory said that Feng Shui was applied for environmentally harmonious living. Herewith, it would be described and analysed that each methods could be syntesized logically without breaking basic Feng Shui rules. It could be concluded that form and formula in Feng Shui were not two separated things, they were complementary to each other and to be used altogether for a good design.
\end{abstract}

Keywords: form, formula, feng shui, methods, design

\begin{abstract}
ABSTRAK
Feng Shui merupakan ilmu Tiongkok kuno yang digunakan sebagai salah satu pendekatan desain dan penataan lingkungan binaan hingga zaman ini. Namun, banyak pihak lupa, tidak sadar, atau bahkan tidak tahu bahwa Feng Shui juga mementingkan bentuk (form) dan bukan hanya penerapan formula atau perhitungan saja. Masalah muncul pada image praktisi Feng Shui yang negatif, yaitu bagi mayoritas arsitek, pelaksana bangunan dan sebagian pihak pemilik proyek, jika praktisi Feng Shui terlibat, desain akan berantakan, aneh, tidak enak dilihat, dan membuat bingung mereka semua. Makalah ini mendeskripsikan dan menganalisis empat pendekatan yang lazim diterapkan oleh praktisi Feng Shui yang pada praktiknya lebih banyak menekankan penerapan formula dan melupakan bentuk (form), padahal teori dasar Feng Shui menyatakan bahwa penerapannya menitikberatkan keserasian dengan lingkungan. Di sini juga ditunjukkan bahwa masing-masing pendekatan dapat ditengahi secara logis tanpa menyalahi aturan dasar Feng Shui itu sendiri. Hasil pembahasan memperlihatkan bahwa bentuk (form) dan penerapan formula dalam Feng Shui bukan merupakan hal yang saling terpisah, tetapi justru diperlukan diterapkan bersamaan untuk tujuan desain yang baik.
\end{abstract}

Kata Kunci: form, bentuk, formula, feng shui, desain, lingkungan binaan

* Fakultas Teknik Program Studi Arsitektur Universitas Katolik Parahyangan Bandung 


\section{PENGANTAR}

Feng Shui secara simbolis sering diartikan sebagai angin dan air. Dalam bahasa Tionghoa, angin dan air tersebut memiliki arti yang lebih luas dari realitas yang sebenarnya sehingga tidaklah heran apabila Feng Shui juga sering kali dihubungkan dengan segala sesuatu yang bersifat takhayul dan mistik. Padahal, yang dibahas dalam Feng Shui sebenarnya sering kali berhubungan dengan segala sesuatu yang bersifat fisik maupun nonfisik dan bukanlah metafisik. Feng Shui merupakan ilmu yang dapat dihitung dan terdeteksi meskipun tetap tidak terlihat karena Feng Shui merupakan ilmu yang berhubungan erat dengan angin dan air sebagai bentuk energi ( $q i / \mathrm{chi}$ ). Dapatlah dimengerti bahwa ciri khas teori Feng Shui sebagai ilmu sering kali "dibaca" dengan penggunaan berbagai jenis formula, seperti angka, simbol, lambang, analogi, dengan tatanan tertentu dalam penerapannya. Sebagai salah satu cabang ilmu budaya dari Tiongkok (The Five Chinese Arts), Feng Shui mengambil garis "pembacaan" sebagai berikut (Tan, 2005):
1. Shan 山: kepercayaan
2. $Y i$ 醫: pengobatan
3. Bu ト: peramalan
4. Xiang 相: pembacaan
5. Shu 術: perhitungan

Feng Shui "membaca” kondisi lingkungan binaan dengan cara mengidentifikasi masalah yang perlu dipecahkan dalam desain dan penataan lingkungan binaan, mulai dari skala benua, negara, kota, hingga ruang-dalam bangunan. Tujuan penggunaan Feng Shui pada dasarnya adalah agar manusia dapat hidup aman, nyaman, dan harmonis/ selaras dengan alamnya.

Dalam praktiknya, terutama sejak awal milenium ini, penerapan formula Feng Shui pada suatu lingkungan binaan terlihat lebih banyak diekspos dan menjadi lebih dikenal masyarakat luas. Sayangnya, mayoritas dari penerapan itu melupakan rekan dari formula itu sendiri, yakni bentuk. Feng Shui menjadi lebih terkenal dengan formulanya; tanpa angka dan simbol, dianggap bukan Feng Shui. Penerapan teori Feng Shui dalam praktiknya lebih menuju kepada formula semata, padahal dalam naskah Tiongkok klasik dinyatakan bahwa perhitungan 峦头无假，理气无真 'Tidak ada "bentuk" yang palsu, tidak ada "formula" yang paling benar' (Yap, 2006).

Hanya sebagian dari praktisi Feng Shui yang menerapkan kalimat klasik tersebut di atas dalam praktiknya. Bagian bentuk justru terlupakan. Bentuk yang diperhitungkan di sini meliputi bentuk awal hingga bentuk akhir, baik pada kondisi makro (lingkungan) maupun mikro (bangunan beserta interior). Lebih jauh mengacu kepada naskah Tiongkok tersebut, Feng Shui sebagai sebuah cabang ilmu pada prinsipnya menyediakan banyak teori dengan latar belakangnya masing-masing, dan bahkan sering diperdebatkan pendekatan mana yang paling "benar". Bagaimanapun bentuk perdebatan itu, secara keilmuan Feng Shui mengandung dua substansi pengetahuan yang selalu ada secara bersamaan, yakni bentuk (form) dan formula (perhitungan) (Kehardthum, 2011).

Hal ini dapat dimaklumi mengingat manusia merupakan mahluk yang mampu beradaptasi. Perkembangan teori apa pun dapat bergeser dari prinsip dasar sesuai dengan kondisi di sekelilingnya sehingga penerapan Feng Shui pun bergeser sesuai dengan kondisi sosial budaya dan fisik lingkungan setempat. Sayangnya, inti bahwa Feng Shui diterapkan untuk manusia dapat hidup lebih nyaman, sekaligus selaras dan harmonis dengan alamnya malah terasa tertinggalkan. Dinyatakan oleh Inajati (2005) bahwa "to make them settle comfortably, they try to adapt to the geographical ecology, to arrange their houses and the related infrastructures, and to adjust them to their believe and their social system". Arti keselarasan dan keharmonisan dengan alam dalam ranah Feng Shui seperti kata-kata belaka yang kurang dimengerti isinya, terbukti dengan terlanggarnya kenyamanan pengguna bangunan setelah Feng Shui diterapkan.

Feng Shui, khususnya di Indonesia, terkenal sebagai ilmu ramal, ilmu klenik, ilmu hitam, dan sejenisnya sehingga Feng Shui tidak disukai oleh sebagian masyarakat. Hal ini tidak lepas dari campur tangan media, cara mengemas, dan cara penyelesaian dari masing-masing praktisi Feng Shui yang dapat datang dari segala penjuru bidang. Teori dan metode Feng Shui semuanya sama sejak awal, tidak pernah berubah. Hal yang berbeda antara para praktisi Feng Shui adalah cara pemecahan masalahnya. Penerapan teori Feng Shui yang begitu bulat-bulat dan cara 
pemecahan masalah dengan kurang logis dan terlihat aneh ataupun tidak enak dilihat, tanpa melihat kondisi setempat, baik kondisi fisik (bangunan dan lingkungannya) maupun nonfisik (kebiasaan pengguna, kondisi sosial budaya setempat) membuat Feng Shui harus memiliki kelompok "musuh" yang pasti, yaitu para arsitek dan kontraktor sebagai pelaksana pembangunan lingkungan binaan.

Feng Shui menjadi dikenal sebagai perusak desain, pembuat bingung pelaksana bangunan, dan pengganggu kegiatan yang jauh dari tujuan dasar penerapan Feng Shui, yaitu kenyamanan, keharmonisan, dan keselarasan manusia dengan lingkungannya. Umum terjadi pada saat pemilik proyek menyatakan ingin menggunakan jasa praktisi Feng Shui dalam proyeknya, arsitek, dan kontraktornya bereaksi negatif, atau bahkan sebaliknya, arsitek atau kontraktor menawarkan penggunaan jasa praktisi Feng Shui dalam proyek langsung ditolak oleh pemilik karena Feng Shui di satu sisi dianggap klenik, mistik, sekaligus menyusahkan, di sisi lain dianggap sebagai perusak desain.

Dalam makalah ini dijabarkan empat teori yang umum digunakan oleh para praktisi Feng Shui (dari sekian ratus teori Feng Shui yang ada), khususnya di Indonesia, yang mayoritas menerapkan formulanya semata tanpa mempertimbangkan bentuk akhir dari hasil sintesisnya. Hasil sintesis penerapan teori Feng Shui tersebut dianalisis dengan menggunakan pendekatan arsitektur, khususnya sehubungan dengan kenyamanan penggunaan dan visual. Penjabaran dilakukan secara deskriptif analitik dari berbagai fenomena yang umum terjadi di Indonesia. Adapun teori Feng Shui yang dipilih untuk menganalisis bentuk (form) dan formula secara bersamaan adalah teori yang populer digunakan yang meliputi aturan umum Feng Shui, teori bentuk (landform), teori kompas (Eight Mansions), dan teori bintang bergerak (Flying Stars).

\section{PENERAPAN KONSEP/ATURAN UMUM FENG SHUI}

Selama ini, Feng Shui telah dicoba dibuat dengan konsep yang disederhanakan dalam bentuk "formula" yang digeneralisasi sehingga masyarakat pengguna, terutama komunitas Tionghoa maupun masyarakat awam lainnya di Indonesia, mengenalnya sebagai "aturan umum" Feng Shui yang dijadikan patokan dalam penerapan di lapangan tanpa mengetahui latar belakang konsep itu sendiri. Adapun pembahasan konsep Feng Shui yang telah digeneralisasi ini meliputi (1) penerapan simbol-simbol Feng Shui, seperti penempelan kertas bertulisan $f u$ (lihat foto 1), penggantungan asesoris berupa simbol dan pemakaian patungpatung dan (2) penerapan angka pada kehidupan sehari-hari, bentuk lahan dan bentuk tangga.

Pada dasarnya, huruf kanji Tionghoa merupakan gambar yang dapat dibuat sedemikian rupa sehingga indah dipandang (Eberhard,

1983). Kertas tulisan $f u$ sering kali terlihat banyak dijual pada waktu Imlek atau Tahun Baru Tionghoa. Tulisan $f u$ secara literal memiliki arti keberuntungan/peruntungan baik dan banyak dihadirkan dengan warna merah sehingga dianggap merupakan warna yang "memberi hidup" (life-giving colour) serta membawa keceriaan yang wajib dihadirkan dalam suasana Imlek. Penelusuran lebih jauh pada berbagai literatur yang ada dapat dikatakan penempelan kertas bertulisan $f u$ ini lebih berfungsi elemen dekoratif yang membawa suasana hati positif, dan bukanlah serta merta membawa keberuntungan, bahkan membawa kemakmuran bagi penggunanya.

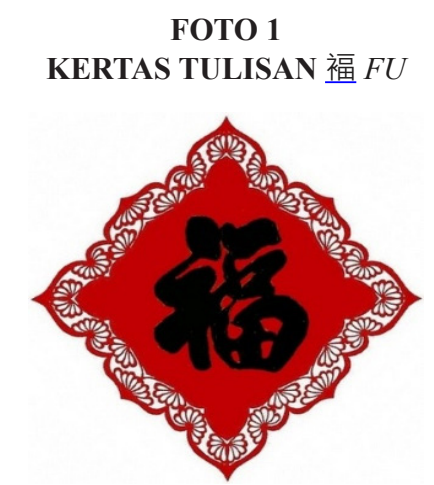

(Sumber : www.chinahighlights.com)

Feng Shui juga sering dikaitkan dengan penggantungan atau pembawaan suatu simbol. Foto 2 memperlihatkan dua simbol yang sering digunakan dengan harapan untuk membawa keberuntungan, yaitu ikan dan lucky/endless knot (ikatan keberuntungan). Pengucapan kata ikan dalam bahasa Mandarin (bahasa orang Tionghoa) yu memiliki arti keberlimpahan, sedangkan lucky 
knot membawa arti panjang dan tidak terputus, yang kemudian dianggap membawa arti panjang usia. Lucky knot ternyata juga digunakan sebagai simbol yang membawa arti baik dalam agama Hindu dan Budha (Eberhard, 1983).

\section{FOTO 2}

IKAN \& LUCKY / ENDLESS KNOT



(Sumber: dokumentasi pribadi)

Selain aksesoris yang digantung, banyak pula dijual patung-patung yang mengarah pada arti kemakmuran. Para pengguna aksesoris dan patung-patung seperti itu sering kali lupa akan kondisi fisik bangunannya sendiri, mereka kurang peka terhadap kadar kenyamanan termasuk masalah penghawaan dan pencahayaan dalam bangunan. Mereka memiliki anggapan bahwa dengan menggantungkan dan menempatkan bendabenda tersebut, Feng Shui sudah diterapkan demi kemakmuran. Tujuan Feng Shui yang sebenarnya bukanlah kemakmuran, melainkan menciptakan lingkungan, rumah yang dapat melindungi, memelihara, bahkan menjadi "tempat suci" untuk penghuninya beristirahat dan memulihkan diri sebelum kembali dapat "menaklukkan dunia" (Yap, 2006).

Setelah melihat perbedaan latar belakang dan tujuan penggunaan simbol dengan Feng Shui, dapat dikatakan bahwa penggunaan simbol ini lebih banyak berhubungan dengan budaya dan tradisi Tionghoa, bukan Feng Shui, yang sebenarnya berhubungan erat dengan kondisi makro (lingkungan) dan mikro (bangunan dan interior). Hal ini menyebabkan Feng Shui seperti terpatri hanya dapat digunakan oleh bangsa Tionghoa dan bukan suku lain.

Simbol yang berhubungan erat dalam Feng Shui adalah simbol warna dan elemen. Penggunaan simbol ini pun pada praktiknya dapat membawa masalah terhadap wujud fisik akhir setelah penerapannya. Orang yang menerapkan tidak mempertimbangkan proporsi dan warna benda yang ditempelkan itu terhadap sekelilingnya. Adalah lumrah pada saat penggunaan simbol ini ditolak oleh pengguna jasa praktisi Feng Shui yang bukan dari bangsa Tionghoa dan memiliki tabu tersendiri dalam penggunaan simbol (warna dan elemen).

Lihat tabel 1. Pada saat pengguna jasa Feng Shui ditetapkan membutuhkan tambahan elemen API, yang terbayang adalah warna merah. Biasanya warna yang ditetapkan sebagai warna baik bagi seseorang langsung digunakan sebagai warna dinding ruang tidur atau rumahnya. Seperti dinyatakan oleh Cahaya Lituhayu (2012), warna merah merupakan warna yang dominan, dapat menaikkan denyut jantung, meningkatkan agresivitas, memicu emosi, serta dapat bersifat menekan. Dapat terbayang apa jadinya jika warna merah dengan tone warna kuat diaplikasikan di seluruh rumah. Dalam budaya Tionghoa sendiri, warna merah dengan tone kuat hanya dihadirkan di rumah ibadat alias di kelenteng dan bukan di rumah tinggal. Itu pun hanya di kolom-kolomnya saja, bukan diwarnakan ke dinding.

Mirip dengan penerapan simbol, penerapan angka juga berhubungan erat dengan budaya dan tradisi komunitas Tionghoa. Hasil wawancara pada beberapa komunitas Tionghoa, terutama yang menerapkan Feng Shui dalam kehidupan sehari-hari, menunjukkan bahwa sebagian besar menghindari apa pun yang menggunakan atau berhubungan dengan angka 4, 14, 24, 34, 40, 41 , apalagi 44, dan seterusnya. Penghindaran penggunaan "formula" angka 4 dalam keseharian mereka disebabkan formula angka 4 memiliki bunyi si yang berarti mati/kematian dalam bahasa Mandarin.

Penghindaran "formula" angka 4 ini terjadi juga dalam pemilihan nomor (jika dapat dipilih), 
mulai dari nomor telepon, nomor rumah, nomor unit, nomor mobil, hingga nomor lantai di gedung-gedung bertingkat banyak. Melakukan penghindaran "formula" angka 4 dianggap oleh sebagian besar penggunanya sudah menerapkan Feng Shui, padahal tulisan angka 4 itu tidak dapat berpengaruh secara fisik maupun nonfisik terhadap kondisi makro (lingkungan) dan mikro (bangunan dan interior) yang merupakan hal yang sebenarnya ditangani Feng Shui.

Angka 4 dalam teori Eight Mansions sebagai salah satu teori Feng Shui justru tidak membawa arti negatif. Keberadaannya sejajar dengan angkaangka lainnya. Angka 4 dalam teori Flying Stars justru dicari-cari merupakan lambang daya pikir, kreativitas, dan perjodohan (Koh, 2003). Sebagai contoh, dalam pemilihan bentuk lahan, dalam Feng Shui justru dicari yang bentuk lahan segiempat murni alias bujur sangkar yang merupakan bentuk terbaik (Yap, 2006). Hal ini sering kali tidak disadari oleh mereka yang menghindari angka 4 tersebut. Di sini mulai terlihat pemahaman "formula" yang bentrok dengan bentuk karena memang tidak ada teori Feng Shui yang menyatakan demikian.

Penerapan angka yang jelas menyimpang dari tujuan penggunaan Feng Shui semula juga terlihat dari penerapan "formula" angka pada jumlah anak tangga. Jumlah anak tangga tertentu dianggap dapat membawa keberuntungan, dalam hal ini adalah 1 dan 2 , beserta kelipatan $5+1$ atau 2 (Too, 1993). Hal ini menyebabkan jumlah anak tangga $6,7,11,12,16,17,21,22$, dan seterusnya menjadi baik adanya, sedangkan jumlah lain tidak.

\section{FOTO 3}

TANGGA TERJAL DAN BERDESAIN BERBAHAYA

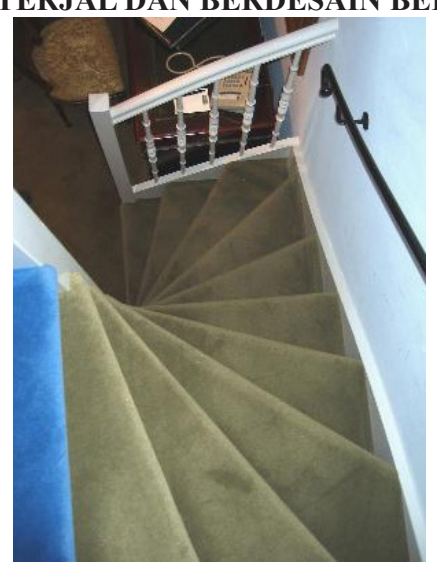

(Sumber: www.tripadvisor.co.uk)
Tangga yang baik (aman dan nyaman) secara teoretis adalah tangga yang tidak memicu terjadinya kecelakaan dan tidak membuat penggunanya kelelahan menaikinya. Sebagai contoh, tangga yang baik adalah tangga yang memiliki bordes. Tangga yang didesain tidak memiliki bordes merupakan tangga yang kurang baik (Kehardthum, 2011) mengingat tangga tersebut dapat menjadi terjal, hingga mencapai tinggi anak tangga $>19$ $\mathrm{cm}$, meskipun jumlah anak tangga dapat sesuai dengan angka "formula" yang diinginkan, yakni 11 buah. Namun, kombinasi ini secara bentuk justru menjadikan tangga tersebut tidak nyaman dan dapat menyebabkan terjadinya kecelakaan saat digunakan. Dengan mengejar jumlah "baik", bentuk yang manusiawi malah terlupakan. Hal ini sering terjadi di tempat sewa, hotel, ruko, dan sejenisnya, yang lebih mengutamakan kata keberuntungan sehingga jumlah anak tangga dengan demikian dapat jadi sesuai dengan "formula", tetapi desain dan tinggi anak tangga menjadi kurang dipikirkan. Hal inilah yang sering menjadi perdebatan para praktisi Feng Shui dengan arsitek yang mengutamakan kenyamanan pengguna bangunan.

Tangga yang nyaman digunakan dengan energi minimum menurut Data Arsitek (Neufert, 2012) dihitung dengan rumus $2 i+t=59-65$ (dengan $\mathrm{i}=$ injakan dalam $\mathrm{cm}, \mathrm{t}=$ tanjakan dalam $\mathrm{cm})$. Jika menggunakan patokan formula Feng Shui, bisa jadi diperoleh tinggi tanjakan yang hebat melebihi batas maksium demi mengejar angka yang tertentu itu. Sudah seharusnya arsitek sebagai perencana dapat mengantisipasi hal ini dengan mengompromikan tinggi lantai yang akan diberi tangga dengan jumlahnya sehingga rumus kenyamanan tangga tersebut terpenuhi. Pada pengembangan teori Feng Shui untuk tangga, dapat digunakan angka ganjil sebagai jumlah total anak tangga yang dituju, bukan lagi patokan angkaangka tersebut di atas sehingga desain tangga menjadi lebih fleksibel dan dapat menjadi lebih nyaman dan aman bagi pengguna (Kehardthum, 2011).

\section{PENERAPAN TEORI BENTUK (LANDFORM)}

Teori landform merupakan interpretasi dari posisi empat binatang langit yang digunakan 
sebagai istilah dalam teori ini. Keempat binatang langit tersebut sebenarnya diambil dari kelompok rasi bintang di Langit Utara Bumi, yaitu Naga Hijau, Macan Putih, Kura-kura Hitam, dan Phoenix Merah (Kehardthum, 2011). Posisi yang dianggap ideal menurut teori bentuk (landform) Feng Shui secara keseluruhan adalah posisi yang dikelilingi (terlindung) oleh keempat binatang langit tersebut dengan komposisi seperti gambar 1 di bawah ini.

Kura-kura Hitam merupakan gunung tertinggi yang diharapkan dapat menjadi sandaran bagi posisi ideal tersebut, Naga Hijau merupakan jajaran gunung tertinggi kedua, Macan Putih merupakan jajaran gunung yang lebih rendah daripada Naga Hijau, dan Phoenix Merah merupakan bukit terendah di bagian depan. Bagian yang banyak terlupakan dalam praktik Feng Shui adalah pertimbangan elemen air datang dan pergi, padahal unsur utama Feng Shui jelas adalah angin dan air. Prinsip dasar Feng Shui, yakni Cang Feng Ju Qi 藏 风聚气 'menangkap angin untuk mengumpulkan energi baik' dengan bantuan gunung dan bukit, kemudian melanjutkannya pada pengumpulannya di air Cheng Feng Zhe San, Jie Shui Zhe Zhi 乘風 則散,界水則止 (Qi is dispersed by the wind and gathers at the boundaries of water-Yap, 2006).

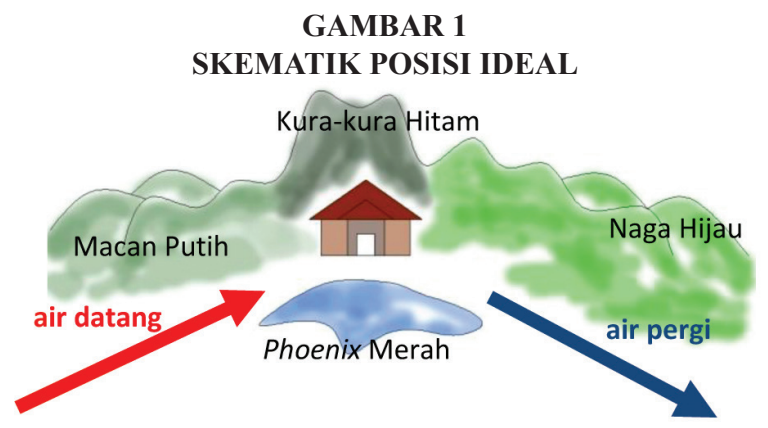

(Sumber: Kehardthum, 2011)

Teori landform ini pada umumnya digunakan dalam pemilihan lahan/posisi ideal yang baik untuk tinggal ataupun untuk bisnis. Analogi keempat binatang langit pun mulai berkembang dan dapat digunakan di area perkotaan yang tidak memiliki gunung dan air secara alamiah. Pada saat inilah, interpretasi masing-masing individu berlainan, termasuk para praktisi sendiri. Pemilihan lahan/posisi ideal di area perkotaan dengan menggunakan teori landform ini menjadi tidak dimungkinkan menurut sebagian praktisi, dengan tidak hadirnya gunung dan air alami, sehingga sering kali justru ditinggalkan. Para praktisi lebih memilih langsung menerapkan "formula" dari teori manapun tanpa melihat kondisi landform yang sebenarnya merupakan perwujudan dari ke empat binatang langit tersebut meski bentuknya adalah lingkungan buatan dan bukanlah lingkungan yang alami. Inilah yang menyebabkan suatu "formula" dari teori tertentu belum tentu dapat menyelesaikan permasalahan yang terjadi jika melupakan "formula" landform yang sebenarnya.

Hampir semua elemen perkotaan merupakan lingkungan buatan, bahkan (jika ada) sungainya sekalipun. Bentuk akhir lingkungan buatan dianggap lebih banyak berpengaruh kepada kondisi yang sedang berjalan, tetapi jika lingkungan buatan tersebut cenderung "merusak", dengan kata lain memotong bukit/gunung secara ekstrem, dalam Feng Shui dikatakan memotong nadi Naga, sehingga dapat dikatakan merusak energi baik itu sendiri. Menurut He Xiao Xin (2007), … 地 者, 万物之本源， $\cdots$ 水者, 地之血 气，如 筋脉之流通者也 'bumi, asal usul berpuluh- ribu benda, ... air, darah bumi, seperti denyut nadi yang mengalir'. Jika lingkungan buatan tersebut merupakan hasil pengubahan secara ekstrim lingkungan alami awalnya, lingkungan buatan tersebut dianggap tidak mampu meningkatkan energi baik yang sudah di rusak sedari awal. Dengan demikian, sering kali pencarian data awal sejarah lahan menjadi penting untuk mendeteksi kemurnian energi positif awal yang diinginkan dan energi negatif awal yang perlu diwaspadai.

Teori landform sebenarnya tidak terpaku oleh keempat binatang langit dalam skala mikro. Skala kota sudah termasuk skala mikro jika dibandingkan dengan skala benua. Kondisi landform bumi yang relatif tetap dalam jangka waktu lama ini membawa peruntungan yang masing-masing berbeda bagi tiap benua, tiap negara, tiap kota, tiap tempat. Hal inilah yang memengaruhi peruntungan negaranegara di Amerika dan Eropa yang menjadi jauh lebih dahulu maju dibandingkan negara di benua lainnya (Kehardthum, 2011). Sementara itu, kotakota tua di Tiongkok telah mempertimbangkan teori landform tanpa formula yang rumit. Patokan yang digunakan dalam memilih posisi kota adalah 
Sungai Kuning dan Sungai Yangtze (Yan \& Sun, 2012).

Pada praktiknya, teori landform ini hanya digunakan oleh sebagian kecil praktisi, untuk skala mikro, yakni hanya melihat bangunan yang ada tepat di belakang, di depan, di kiri dan kanan lahan/posisi yang diinginkan. Pengidentifikasian air datang dan pergi tidak banyak dilakukan karena masing-masing praktisi pada akhirnya memiliki pertimbangan berbeda akibat variasi teori air dalam Feng Shui yang beraneka ragam dan teori air masih lebih banyak tersimpan dalam naskah berbahasa Mandarin.

Dalam skala yang lebih mikro, penerapannya dalam ruang-bangunan, teori landform ini kemudian berfusi dengan kedelapan arah mata angin dan mulai dihubungkan dengan warna dan elemen masing-masing sektor mata angin.

TABEL 1

RELASI MATA ANGIN, ELEMEN DAN WARNA

\begin{tabular}{lll}
\hline Mata Angin & \multicolumn{1}{c}{ Elemen } & \multicolumn{1}{c}{ Warna } \\
\hline Utara & Air & Hitam, Abu, Biru \\
Timur Laut & Tanah Kecil & Coklat, Kuning \\
Timur & Kayu Besar & Hijau \\
Tenggara & Kayu Kecil & Hijau \\
Selatan & Api & Merah, Ungu, Oranye, Pink \\
Barat Daya & Tanah Besar & Coklat, Kuning \\
Barat & Logam Besar & Putih, Emas, Perak \\
Barat Laut & Logam Kecil & Putih, Emas, Perak \\
Tengah & Tanah & Coklat, Kuning \\
\hline
\end{tabular}

(Sumber: Lo, 2005/Atherton, 2000)

Pada tabel 1 , jika seluruh alternatif warna digunakan, meskipun "formula" yang digunakan terlihat "benar" ditinjau dari teori ini, satu bangunan akan terlihat terlalu berwarna-warni. Warna-warni ini hanya terlihat harmonis dan selaras jika menggunakan nada warna yang sejenis. Hal ini perlu mendapat perhatian dari praktisi bahwa warna-warni tersebut perlu diselaraskan dengan batasan tertentu. Sebagai contoh, penggunaan warna dalam ruangan dengan nada yang kuat. Bayangkan ruang tidur yang jatuh di sektor Selatan memilih warna pink yang diartikan merah muda, tetapi nada pink yang dipilih adalah nada kuat yang menyolok mata. Secara teoretis, menurut tinjauan Feng Shui, penggunaan warna pink di sektor Selatan benar, tetapi jika warna kuat ini hadir di sekeliling ruang tidur, maka kemungkinan pengguna ruang tidak dapat tidur dengan nyenyak.

Selain warna, elemen juga dapat disejajarkan dengan bentuk, sebagai berikut.

TABEL 2

RELASI ELEMEN DAN BENTUK

\begin{tabular}{cc}
\hline Elemen & Bentuk \\
\hline Kayu & Persegi panjang \\
Api & Segitiga/Tajam \\
Tanah & Bujursangkar \\
Logam & Lingkaran/Bundar/Bulat \\
Air & Melengkung-lengkung
\end{tabular}

(Sumber: Lo, 2005)

Jika seseorang dianjurkan menggunakan bentuk-bentuk yang melambangkan elemen LOGAM, alias bentuk-bentuk lingkaran/bundar/ bulat, penggunaannya pun dianjurkan proporsional. Bentuk-bentuk lingkaran/bundar/bulat dalam aplikasi yang berlebihan dapat membuat orang yang melihat menjadi pusing, terlebih jika warna yang digunakan juga terlalu variatif.

Foto 4

Pola Lingkaran yang Digunakan dalam Tone Kuat dan dapat Dikatakan Berlebihan dalam Ruang Tidur

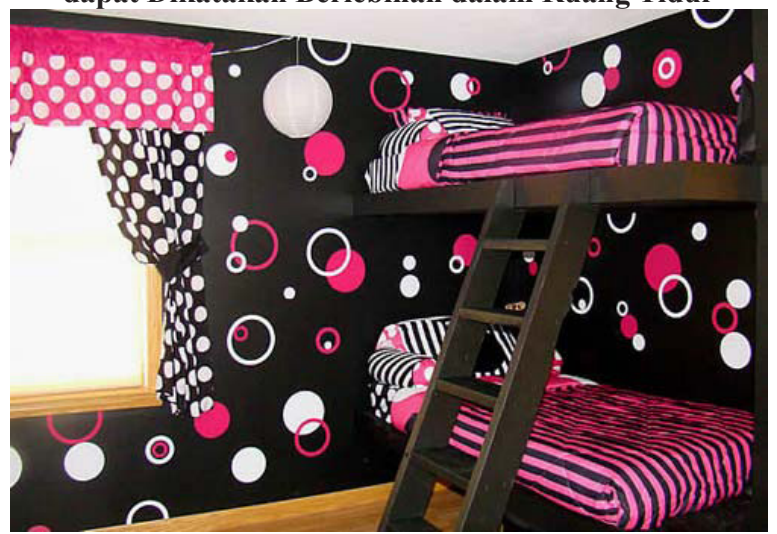

(Sumber: www.girraweenhouse.com) 
Foto 5

Pola Lingkaran yang Digunakan Proporsional dalam Ruang Duduk

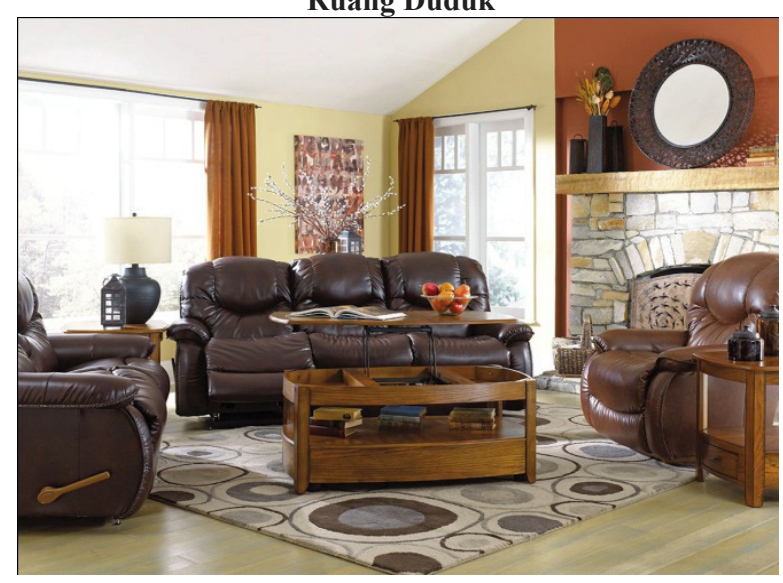

(Sumber: www.linkezy.com)

\section{PENERAPAN TEORI KOMPAS (EIGHT MANSIONS)}

Teori Kompas/Eight Mansions dapat dikatakan sebagai teori yang paling populer di Indonesia terlihat dari maraknya buku dan tulisan yang menampilkan formula dari teori ini. Kepopuleran itu didukung oleh kesederhanaan formulanya yang membagi semua orang di dunia ini menjadi dua kelompok saja untuk menentukan arah/sektor yang baik bagi masing- masing orang, yaitu kelompok Timur dan kelompok Barat, berdasarkan tahun kelahirannya. Pergantian tahun dihitung mulai tanggal 3/4/5 Februari setiap tahunnya mengikuti Kalender Hsia (Kalender 10.000 tahun), bukan Kalender Lunar yang permulaan tahunnya berbeda tanggal Masehi setiap tahun. Penentuan arah baikburuk ditentukan oleh angka GUA masing-masing, dibedakan jenis kelamin pria atau wanita. Lihat tabel 3.

Kelompok Timur (GUA 1, 3, 4, 9) memperoleh arah/sektor baik yang meliputi Timur, Tenggara, Utara dan Selatan, sedangkan kelompok Barat (GUA 2, 5, 6, 7, 8) memperoleh arah/sektor baik yang meliputi Barat, Barat Daya, Timur Laut, dan Barat Laut. Arah/sektor yang baik bagi kelompok Timur merupakan arah/sektor yang tidak baik bagi kelompok Barat, dan sebaliknya. Lihat tabel 4 dan 5.

Tabel 3

Tabel Angka GUA Tahun 1969 sampai 2020

\begin{tabular}{|c|c|c|c|c|c|c|c|c|c|}
\hline Shio & Mulai & Akhir & Pria & Wanita & Shio & Mulai & Akhir & Pria & Wanita \\
\hline Tikus & 5 Feb 1948 & 3 Feb 1949 & 7 & 8 & Tikus & 4 Feb 1984 & 3 Feb 1985 & 7 & 8 \\
\hline Kerbau & 4 Feb 1949 & 3 Feb 1950 & 6 & 9 & Kerbau & 4 Feb 1985 & 3 Feb 1986 & 6 & 9 \\
\hline Macan & 4 Feb 1950 & 3 Feb 1951 & 5 & 1 & Macan & 4 Feb 1986 & 3 Feb 1987 & 5 & 1 \\
\hline Kelinci & 4 Feb 1951 & 4 Feb 1952 & 4 & 2 & Kelinci & 4 Feb 1987 & 3 Feb 1988 & 4 & 2 \\
\hline Naga & 5 Feb 1952 & 3 Feb 1953 & 3 & 3 & Naga & 4 Feb 1988 & 3 Feb 1989 & 3 & 3 \\
\hline Ular & $4 \mathrm{Feb} 1953$ & 3 Feb 1954 & 2 & 4 & Ular & 4 Feb 1989 & 3 Feb 1990 & 2 & 4 \\
\hline Kuda & 4 Feb 1954 & 3 Feb 1955 & 1 & 5 & Kuda & 4 Feb 1990 & 3 Feb 1991 & 1 & 5 \\
\hline Kambing & 4 Feb 1955 & 4 Feb 1956 & 9 & 6 & Kambing & 4 Feb 1991 & 3 Feb 1992 & 9 & 6 \\
\hline Monyet & 5 Feb 1956 & 3 Feb 1957 & 8 & 7 & Monyet & 4 Feb 1992 & 3 Feb 1993 & 8 & 7 \\
\hline Ayam & $4 \mathrm{Feb} 1957$ & 3 Feb 1958 & 7 & 8 & Ayam & 4 Feb 1993 & 3 Feb 1994 & 7 & 8 \\
\hline Anjing & 4 Feb 1958 & 3 Feb 1959 & 6 & 9 & Anjing & 4 Feb 1994 & 3 Feb 1995 & 6 & 9 \\
\hline Babi & 4 Feb 1959 & 4 Feb 1960 & 5 & 1 & Babi & 4 Feb 1995 & 3 Feb 1996 & 5 & 1 \\
\hline Tikus & 5 Feb 1960 & 3 Feb 1961 & 4 & 2 & Tikus & 4 Feb 1996 & 3 Feb 1997 & 4 & 2 \\
\hline Kerbau & 4 Feb 1961 & 3 Feb 1962 & 3 & 3 & Kerbau & 4 Feb 1997 & 3 Feb 1998 & 3 & 3 \\
\hline Macan & 4 Feb 1962 & 3 Feb 1963 & 2 & 4 & Macan & 4 Feb 1998 & 3 Feb 1999 & 2 & 4 \\
\hline Kelinci & 4 Feb 1963 & 4 Feb 1964 & 1 & 5 & Kelinci & 4 Feb 1999 & 3 Feb 2000 & 1 & 5 \\
\hline Naga & 5 Feb 1964 & 3 Feb 1965 & 9 & 6 & Naga & 4 Feb 2000 & 3 Feb 2001 & 9 & 6 \\
\hline Ular & 4 Feb 1965 & 3 Feb 1966 & 8 & 7 & Ular & 4 Feb 2001 & 3 Feb 2002 & 8 & 7 \\
\hline Kuda & 4 Feb 1966 & 3 Feb 1967 & 7 & 8 & Kuda & 4 Feb 2002 & 3 Feb 2003 & 7 & 8 \\
\hline Kambing & 4 Feb 1967 & 4 Feb 1968 & 6 & 9 & Kambing & 4 Feb 2003 & 3 Feb 2004 & 6 & 9 \\
\hline
\end{tabular}




\begin{tabular}{|c|c|c|c|c|c|c|c|c|c|}
\hline Shio & Mulai & Akhir & Pria & Wanita & Shio & Mulai & Akhir & Pria & Wanita \\
\hline Monyet & 5 Feb 1968 & 3 Feb 1969 & 5 & 1 & Monyet & 4 Feb 2004 & 3 Feb 2005 & 5 & 1 \\
\hline Ayam & 4 Feb 1969 & 3 Feb 1970 & 4 & 2 & Ayam & 4 Feb 2005 & 3 Feb 2006 & 4 & 2 \\
\hline Anjing & 4 Feb 1970 & 3 Feb 1971 & 3 & 3 & Anjing & 4 Feb 2006 & 3 Feb 2007 & 3 & 3 \\
\hline Babi & 4 Feb 1971 & 4 Feb 1972 & 2 & 4 & Babi & 4 Feb 2007 & 3 Feb 2008 & 2 & 4 \\
\hline Tikus & 5 Feb 1972 & 3 Feb 1973 & 1 & 5 & Tikus & 4 Feb 2008 & 3 Feb 2009 & 1 & 5 \\
\hline Kerbau & 4 Feb 1973 & 3 Feb 1974 & 9 & 6 & Kerbau & 4 Feb 2009 & 3 Feb 2010 & 9 & 6 \\
\hline Macan & 4 Feb 1974 & 3 Feb 1975 & 8 & 7 & Macan & 4 Feb 2010 & 3 Feb 2011 & 8 & 7 \\
\hline$\underline{\text { Kelinci }}$ & 4 Feb 1975 & 4 Feb 1976 & 7 & 8 & Kelinci & 4 Feb 2011 & 3 Feb 2012 & 7 & 8 \\
\hline Naga & 5 Feb 1976 & 3 Feb 1977 & 6 & 9 & Naga & 4 Feb 2012 & 3 Feb 2013 & 6 & 9 \\
\hline Ular & 4 Feb 1977 & 3 Feb 1978 & 5 & 1 & Ular & 4 Feb 2013 & 3 Feb 2014 & 5 & 1 \\
\hline Kuda & 4 Feb 1978 & 3 Feb 1979 & 4 & 2 & Kuda & 4 Feb 2014 & 3 Feb 2015 & 4 & 2 \\
\hline Kambing & 4 Feb 1979 & 4 Feb 1980 & 3 & 3 & Kambing & 4 Feb 2015 & 3 Feb 2016 & 3 & 3 \\
\hline Monyet & 5 Feb 1980 & 3 Feb 1981 & 2 & 4 & Monyet & 4 Feb 2016 & 2 Feb 2017 & 2 & 4 \\
\hline Ayam & 4 Feb 1981 & 3 Feb 1982 & 1 & 5 & Ayam & 3 Feb 2017 & 3 Feb 2018 & 1 & 5 \\
\hline Anjing & 4 Feb 1982 & 3 Feb 1983 & 9 & 6 & Anjing & 4 Feb 2018 & 3 Feb 2019 & 9 & 6 \\
\hline Babi & 4 Feb 1983 & 3 Feb 1984 & 8 & 7 & Babi & 4 Feb 2019 & 3 Feb 2020 & 8 & 7 \\
\hline
\end{tabular}

(Sumber : Koh, 2003)

Tabel 4

Tabel arah baik menurut angka GUA

\begin{tabular}{cccccc}
\hline GOL. & GUA & $\begin{array}{c}\text { ARAH } \\
\text { KEMAKMURAN }\end{array}$ & $\begin{array}{c}\text { ARAH } \\
\text { KESEHATAN }\end{array}$ & $\begin{array}{c}\text { ARAH } \\
\text { KEHARMONISAN }\end{array}$ & $\begin{array}{c}\text { ARAH } \\
\text { PERTUMBH AN }\end{array}$ \\
\hline TIMUR & 1 & TENGGARA & TIMUR & SELATAN & UTARA \\
BARAT & 2 & TIMUR LAUT & BARAT & BARAT LAUT & BARAT DAYA \\
TIMUR & 3 & SELATAN & UTARA & TENGGARA & TIMUR \\
TIMUR & 4 & UTARA & SELATAN & TIMUR & TENGGARA \\
BARAT & 6 & BARAT & TIMUR LAUT & BARAT DAYA & BARAT LAUT \\
BARAT & 7 & BARAT LAUT & BARAT DAYA & TIMUR LAUT & BARAT \\
BARAT & 8 & BARAT DAYA & BARAT LAUT & BARAT & TIMUR LAUT \\
TIMUR & 9 & TIMUR & TENGGARA & UTARA & SELATAN \\
& \multicolumn{7}{c}{ Gua 5 ambil Gua 2 untuk PRIA, dan Gua 8 untuk WANITA } & \\
\hline
\end{tabular}

(Sumber : Koh, 2003)

Tabel 5

Tabel arah buruk menurut angka GUA

\begin{tabular}{cccccc}
\hline GOL. & GUA & $\begin{array}{c}\text { ARAH } \\
\text { KESIALAN }\end{array}$ & $\begin{array}{c}\text { ARAH KETIDAK- } \\
\text { HARMONISAN }\end{array}$ & ARAH PENYAKIT & $\begin{array}{c}\text { ARAH } \\
\text { KEHANCURAN }\end{array}$ \\
\hline TIMUR & 1 & BARAT & TIMUR LAUT & BARAT LAUT & BARAT DAYA \\
BARAT & 2 & TIMUR & TENGGARA & SELATAN & UTARA \\
TIMUR & 3 & BARAT DAYA & BARAT LAUT & TIMUR LAUT & BARAT \\
TIMUR & 4 & BARAT LAUT & BARAT DAYA & BARAT & TIMUR LAUT \\
BARAT & 6 & TENGGARA & TIMUR & UTARA & SELATAN \\
BARAT & 7 & UTARA & SELATAN & TENGGARA & TIMUR \\
BARAT & 8 & SELATAN & UTARA & TIMUR & TENGGARA \\
TIMUR & 9 & TIMUR LAUT & BARAT & BARAT DAYA & BARAT LAUT \\
& \multicolumn{7}{c}{ Gua 5 ambil Gua 2 untuk PRIA, dan Gua 8 untuk WANITA } & \\
\hline
\end{tabular}

(Sumber : Koh, 2003)
Penerapan formula ini pada praktiknya sering kali menyebabkan terjadinya varian arah hadap pintu masuk utama bangunan yang tidak tegak lurus jalan di depannya. Misalnya, lahan yang dimiliki hadap Selatan, padahal pemilik termasuk kelompok Barat. Arah/sektor Selatan termasuk tidak baik bagi kelompok Barat. Kemungkinan pemutaran arah hadap bangunan menjadi ke arah/ sektor Tenggara atau arah/sektor Barat Daya. Untuk kelompok Barat, dalam kondisi seperti ini mau tidak mau memilih arah dan sektor Barat Daya agar arah/sektor baik terpenuhi. Terlihat pada gambar 2 bahwa pintu masuk utama bangunan menjadi tidak tegak lurus jalan. Penyelesaian seperti ini banyak tidak disukai oleh para arsitek karena dianggap mengganggu tampak bangunan. Kemampuan para arsitek benar- benar diuji agar bangunan tidak terlihat "aneh" pada bentuk akhirnya nanti. Pada praktiknya, kemiringan pintu masuk utama $45^{\circ}$ biasanya merupakan pilihan yang masih dapat ditangani dengan lebih mudah pada desain. Pada beberapa kasus lainnya ada juga kejadian bahwa kemiringan pintu masuk utama memiliki derajat kemiringan bukan $45^{\circ}$, misalnya $12^{\circ}$ atau angka lain yang jarang digunakan dalam desain pada umumnya. Kondisi seperti ini menyebabkan tampak muka bangunan menjadi tidak lazim, seperti mulut yang miring, tidak searah dengan muka yang sedang hadap lurus jalan. 
Gambar 2

Skematik Denah Posisi Pintu Masuk Utama di sektor Lahan Hadap Selatan, yang Termasuk Kelompok Barat

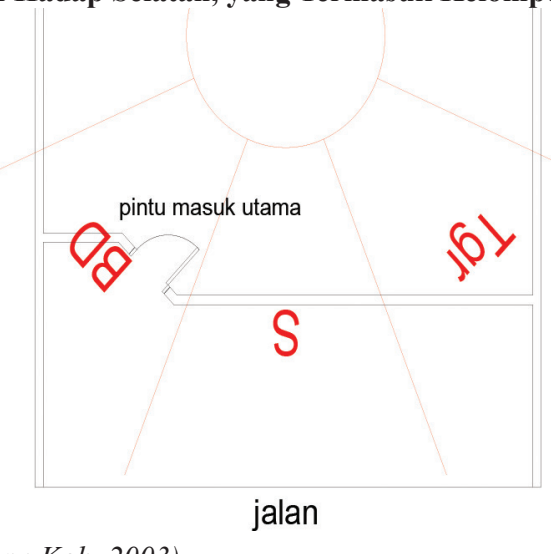

(Sumber : Koh, 2003)

Jika diperiksa kembali dengan prinsip Feng Shui yang memegang dua hal yaitu bentuk dan formula, maka terlihat bahwa penyelesaian seperti itu memang hanya didasarkan pada formula tanpa memperhatikan bentuk sama sekali. Bentuk yang dimaksud di sini sama dengan telah dikaji sebelumnya, yaitu bentuk akhir terhadap kondisi lingkungan sebagai elemen makro yang tidak dapat ditiadakan. Dari gambar 2 terlihat bahwa pintu masuk utama dalam kondisi seperti itu malah menghadap ke dinding pembatas tetangga, padahal pintu masuk utama sebagai mulut bagi masuknya energi (angin dan hawa) tidak dianjurkan dihalangi (Kehardthum, 2011). Area pintu masuk utama menjadi tidak terlalu nyaman untuk diakses. Pemecahan yang biasa dilakukan untuk hal ini biasanya adalah dengan melubangi atau membuat dinding pembatas dengan tetangga itu menjadi pagar yang berlubang-lubang, sehingga angin dan hawa yang diinginkan dapat masuk ke arah pintu masuk utama secara langsung, tidak terhalangi lagi oleh dinding masif.

Selain masalah varian arah hadap pintu masuk utama, terdapat juga permasalahan lainnya, yakni varian arah lalu lintas, baik arah lalu lintas satu arah maupun dua arah. Arah arus lalu lintas merupakan bentuk energi air, sebagai pengganti sungai, kali, laut, dan sejenisnya, di area perkotaan (Koh, 2003). Energi air itu sendiri merupakan energi yang dicari dalam Feng Shui, sebagai lambang kemakmuran pada umumnya. Menyambung dari pintu masuk utama sebagai mulut bagi masuknya energi, jika air sulit masuk, dalam Feng Shui dapat ditetapkan sebagai pintu masuk utama yang kurang ideal (kemakmuran pun menjadi sulit masuk).

Gambar 3

Skematik Denah Arah Lalu Lintas Dua Arah A dan B terhadap Pintu Masuk Utama

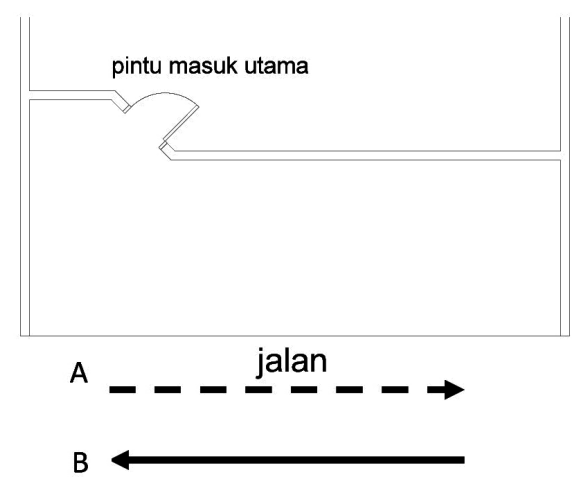

Arah air yang diinginkan adalah air datang dan bukan air pergi (Koh, 2003). Jika lahan seperti yang tergambar pada gambar 3 terletak di posisi jalan dengan dua arah, maka pintu masuk utama tersebut memperoleh kedua arah air, baik datang ( $\operatorname{arah}$ A) maupun pergi (arah B). Permasalahannya adalah arah arus lalu lintas bukanlah hak dari pemilik lahan untuk mengatur. Jika suatu saat pemerintah mengubah arah arus lalu lintas tersebut menjadi satu arah, pemilik lahan hanya dapat menerima kondisi perubahan tersebut. Seandainya arah arus lalu lintas menjadi A saja, hal tersebut tidak bermasalah karena pintu masuk utama itu berarti menerima air datang. Namun, sebaliknya, seandainya arus lalu lintas menjadi B saja, hal ini termasuk hal yang dihindari menurut perhitungan Feng Shui karena B merupakan arus pergi. Secara teoretis, penghuni lahan cenderung akan mengalami lebih banyak pengeluaran (peruntungan baik tertarik menjauh). Hal inilah salah satu penyebab penggunaan teori Eight Mansion dianjurkan digabungkan dengan teori lanjutannya, yaitu teori Xuan Kong Da Gua. Sayangnya, sebagian besar praktisi tidak melanjutkan ke tahap tersebut hanya berhenti hingga titik ini saja, sehingga penanganan terhadap hal seperti ini dapat terlewat begitu saja.

Dalam skala mikro, penerapan teori Eight Mansions secara harfiah juga dapat mengganggu alur kegiatan dalam bangunan. Sebagai contoh, dalam desain rumah tinggal, pada desain akhir 
dapur harus terlebih dahulu untuk menuju ruang makan, tempat sektor buruk dipilih menjadi dapur tersebut. Pada kasus lain, misalnya, posisi kamar mandi menjadi jauh dari ruang-ruang tidur karena sektor buruk berada jauh dari ruang-ruang tersebut. Dalam hal ini kenyamanan pengguna kembali terlanggar tanpa sadar meskipun secara formula adalah benar.

Contoh lain, dalam rumah tinggal, mayoritas penghuni tetap adalah keluarga yang beranggotakan lebih dari satu orang, yang bukan tidak mungkin terdiri dari dua kelompok sekaligus, kelompok Timur dan Barat yang membutuhkan arah/sektor baik yang saling berkebalikan. Bahkan, suami istri pun dapat menghasilkan arah/sektor yang benar-benar saling berkebalikan. Jika bersikeras menggunakan arah/sektor yang baik bagi masingmasing, dapat dipastikan suami istri tersebut tidak dapat menempati dalam ruang tidur utama yang sama atau jika salah satu mengalah menggunakan ruang tidur yang sama dan memaksa menggunakan arah tidur yang baik bagi masing-masing, berarti kepala sang suami akan bertemu kaki sang istri dan sebaliknya. Hal ini kembali merupakan gangguan terhadap kenyamanan demi arah. Pemecahan masalah ini sering kali pada akhirnya adalah dengan kompromi penggunaan arah/sektor yang baik keharmonisan atau pertumbuhan agar arah/ sektor buruk yang diperoleh pasangannya termasuk arah kesialan dan ketidakharmonisan. Hal ini berarti tidak dapat menggunakan arah/sektor kemakmuran atau kesehatan agar pasangannya tidak memperoleh arah/sektor kehancuran atau penyakit.

Dalam teori Eight Mansions terdapat istilah arah ketidakharmonisan, yaitu $W u$ Gui 五鬼 yang secara literal diterjemahkan sebagai Five Ghost/ Lima Setan (Koh, 2003). Naskah Feng Shui klasik kebanyakan dipresentasikan dalam bentuk syair dan peribahasa empat huruf. Sehubungan dengan $W u$ Gui ini, terdapat kalimat yang cukup akrab bagi praktisi dan pemerhati Feng Shui, yaitu Wu Gui Ying Cai 五鬼迎財 yang diterjemahkan literal sebagai Five Ghost Carrying Wealth/ Lima Setan Pembawa Kemakmuran. Teori Eight Mansions sebenarnya tidak ada hubungannya dengan teori Five Ghost Carrying Wealth yang merupakan salah satu teori air (water theory) dari sekian ratus teori air dalam Feng Shui (Lo, 2005).
Teori air Five Ghost Carrying Wealth menjadi populer karena kemudahan dalam penerapannya. Namun, pengetahuan mengenai teori air yang tidak menyebar sepopuler Eight Mansions menyebabkan yang terdengar hanyalah istilahnya saja dan kebetulan memiliki kesamaan yang sama separuh bagian saja yaitu $W u$ Gui. Pada akhirnya, yang terjadi adalah pengaktifan area $W u$ Gui dengan harapan dapat membawa kemakmuran, padahal menurut teori Eight Mansions, sektor Wu Gui justru termasuk sektor buruk yang tidak layak diaktifkan.

Pernah terjadi pemasangan lampion merah lima buah di sektor $W u$ Gui dengan alasan merupakan penerapan teori Five Ghost Carrying Wealth. Secara kebetulan, kelima lampu merah tersebut berada di ruang makan. Dapat dibayangkan bagaimana rasanya makan di ruang yang serba merah, terlepas dari benar tidaknya cara penerapan teori yang setengah-setengah tersebut. Di sini terlihat jelas bahwa formula berada di atas segalanya, nyaman atau tidak nyaman, lazim atau tidak lazim adalah urusan belakangan atau bahkan tidak dipedulikan. Hal ini sering terlihat di restoran-restoran Tionghoa, tetapi berbeda dengan suasana di dalam satu ruang makan, di restoran justru masih dapat terlihat layak dan bahkan berkesan mewah.

Foto 6

Set Lima Lampion Merah di Lounge dan Ruang Makan di Red Lantern Foxwood, Foxwoods Casino, Connecticut, Amerika Serikat

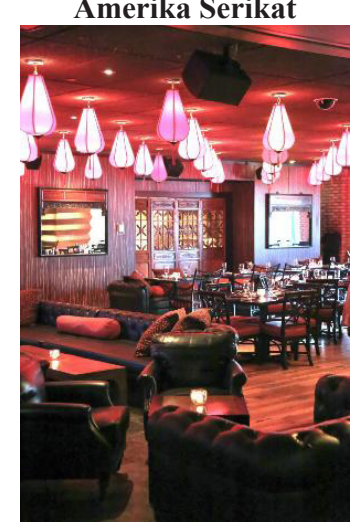

(Sumber: www.tripadvisor.com)

\section{PENERAPAN TEORI BINTANG BERGERAK (FLYING STARS)}

Satu lagi teori Feng Shui yang berkembang 
pesat belakangan ini adalah teori Bintang Bergerak (Flying Stars). Teori ini menggunakan arah mata angin sebagai unsur utama. Delapan arah mata angin dibagi menjadi 24 arah subsektor mata angin, masing-masing arah mata angin dibagi tiga sehingga arah Timur menjadi Timur 1, Timur 2, Timur 3, atau sering juga ditulis sebagai Timur 1, Timur, Timur 2, dengan maksud sama (Koh, 2003). Waktu penggunaan bangunan pertama kalinya dan ukuran arah hadap bangunan menjadi patokan pembentukan diagram Flying Stars, untuk kemudian menjadi dasar analisis dengan teori Flying Stars. Seperti terlihat pada gambar 4, angka-angka dalam diagram itulah yang disebut dengan istilah stars/bintang dalam teori ini. Pada teori Flying Stars, waktu dibagi menjadi 9 periode, yang akan membawa arti berbeda di masingmasing periode (timely dan untimely) (Koh, 2003). Gambar 4 menunjukkan diagram Flying Stars untuk bangunan hadap Barat yang digunakan pertama kali di periode 8 . Angka periode terbaca pada angka terbesar di kotak bagian paling tengah. Analisis selanjutnya menggunakan angka-angka kecil di depan dan di belakang angka-angka besar untuk menentukan sektor mana yang baik untuk apa dan sektor mana yang tidak baik untuk apa. Penerapan teori Flying Stars ini dalam denah bangunan yang dianalisis mirip dengan teori Eight Mansions yang dibahas sebelum ini. Perbedaannya adalah pada isi tiap sektor yang pada teori ini selalu berisi tiga angka untuk penentuan sektor baikburuk yang didasarkan pada arah hadap bangunan, bukan pada perhitungan data lahir pengguna bangunan.

\section{Gambar 4}

Contoh Diagram Flying Stars untuk Bangunan Hadap $266^{\circ}$ dari Utara (Hampir Tepat Hadap Barat)

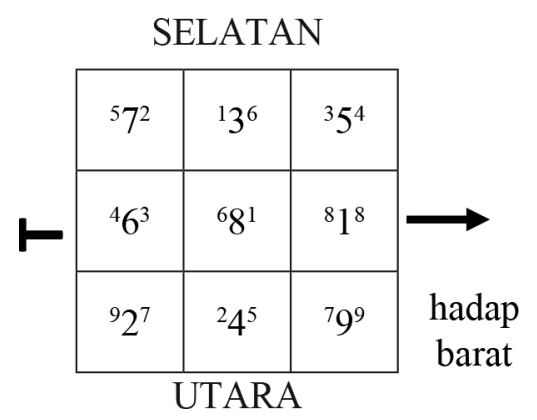

Menurut teori ini, sektor yang dianggap buruk adalah terutama yang memiliki angka kecil 2 dan 5 . Berdasarkan contoh pada gambar 4, sektor buruk jatuh pada posisi Tenggara dengan angka $5 * 7 * 2$ dan posisi Utara dengan angka $2 * 4 * 5$. Pada sektorsektor ini dianjurkan untuk digunakan sebagai kamar mandi, gudang, atau fungsi servis lainnya. Perlu diingat walaupun diarahkan sebagai fungsi servis, tetapi pencahayaan dan penghawaan yang optimal perlu diperhatikan. Hal yang paling sering terjadi sebagai wujud kurangnya relasi antara bentuk dengan formula. Contohnya adalah posisi kamar mandi di sektor Utara (sektor $2 * 4 * 5$ ) yang menempel pada dinding batas Utara serta biasanya merupakan dinding batas dengan tetangga.

Lihat gambar 5. Dengan kondisi seperti itu, kamar mandi adalah sesuai dengan formula, tetapi pencahayaan dan penghawaan tidak ada, apalagi jika denah tersebut merupakan lantai dasar dari bangunan berlantai tingkat. Demikian pula dengan ruang tidur 2 yang posisinya benar menurut formula dengan mountain star 9 di sektor TL (Timur Laut) yang sesuai untuk dijadikan ruang tidur menurut formula Flying Stars (Koh, 2003) secara fisik justru kurang memadai sebagai ruang tidur yang layak disebabkan penghawaan dan pencahayaan tidak optimal dengan hadirnya ruang perpustakaan di belakangnya. Hal ini juga menunjukkan relasi yang kurang sesuai antara bentuk dan formula.

\section{Gambar 5}

Posisi Kamar Mandi yang Sesuai menurut Teori Flying Stars, Tetapi Tanpa Kenyamanan dapat Terasa Baik

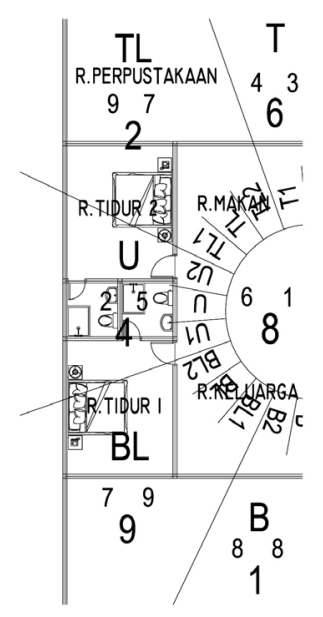

Hal lain yang lazim terjadi karena penggunaan 
teori Flying Stars ini adalah penggunaan water features dalam bentuk kolam ikan, air terjun, atau air mancur. Melanjutkan contoh tadi (gambar 5), sektor Barat mengandung water star 8 yang dapat diaktifkan untuk meningkatkan peruntungan kemakmuran (Koh, 2003). Pada bangunan yang sudah selesai dibangun, biasanya diupayakan menghadirkan dengan water feature interior yang banyak dijual di toko-toko. Keputusannya benar menurut teori Flying Stars ini, tetapi yang dilupakan adalah proporsi. Mayoritas pemilik bangunan berkonsep "asal ada" sehingga yang terjadi adalah kehadiran water feature yang kekecilan sehingga seperti menaruh garam di dalam lautan. Water feature kebesaran juga dapat terjadi menurut pengamatan, tetapi tidak sesering kekecilan. Keputusan untuk mengasal-adakan water feature dianggap tidak akan menghasilkan pengaktifan yang optimal.

Foto 7

Water feature di Rumah Sakit Hoag yang Besarnya

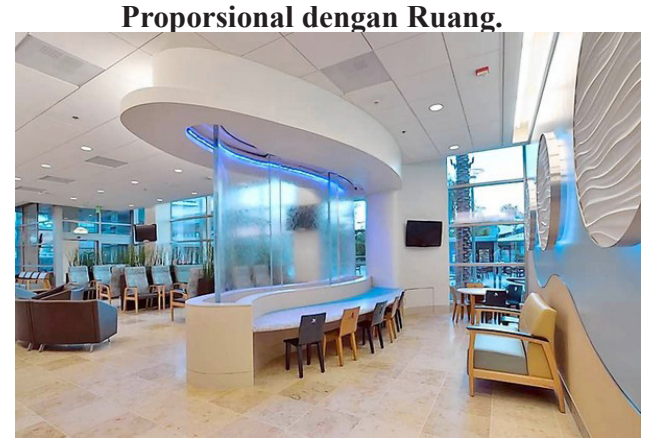

(Sumber: http://articles.dailypilot.com)

Sektor buruk dengan angka $2 * 5$ menurut teori Flying Stars ini selain daripada ditekan dengan menggunakan sektor tersebut sebagai area servis, kamar mandi, gudang dan sejenisnya, juga dapat dengan menghadirkan elemen logam di sektor tersebut (Koh, 2003). Tindakan yang paling umum dilakukan adalah dengan menggantungkan lonceng angin yang terbuat dari bahan logam. Penetralan sektor ini perlu dilakukan dengan jumlah logam yang juga proporsional. Kebanyakan lonceng angin yang dijual di pasaran berukuran kecil.
Foto 8

Contoh Lonceng Logam Berlonceng Enam yang Besarnya Cukup Proporsional dengan Ruangan Memiliki Variasi Kayu Berbentuk Bundar yang Juga Merupakan Lambang Logam

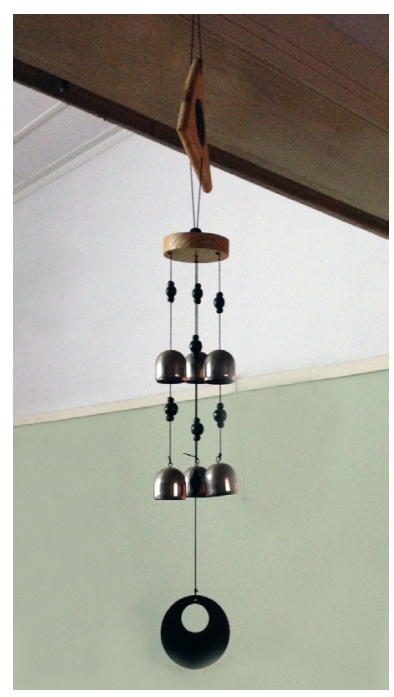

Jika teori dirunut lebih dalam lagi, diketahui bahwa lonceng angin terideal menurut teori Feng Shui adalah yang berkaki enam $($ Lo, 2005) atau berlonceng enam karena angka enam adalah lambang logam kecil yang dianggap baik, dibandingkan dengan angka 7 yang sebenarnya merupakan lambang logam juga. Sering kali yang dilakukan adalah karena lonceng angin berukuran terlalu kecil, lonceng angin digantungkan dengan jumlah banyak untuk mengejar proporsi tersebut. Jika hal ini dilakukan, bukan saja bangunan menjadi seperti toko lonceng angin, tetapi juga berisik dan dapat membuat pengguna bangunan tidak betah berlama-lama di dalam bangunan. Dengan terjadinya hal ini, keharmonisan dan keselarasan pengguna bangunan dengan lingkungan justru tidak dapat terjadi dan hal ini bukan tujuan penerapan teori Feng Shui.

\section{SIMPULAN}

Dari jabaran dengan menggunakan aturan umum Feng Shui dan tiga teori yang populer diketahui oleh masyarakat, khususnya di Indonesia, dapat disimpulkan bahwa selama ini sintesis Feng Shui lebih terpaku pada formula dan aturanaturan dalam teorinya daripada terhadap bentuk, 
dalam hal ini hasil akhir desain dan tanpa banyak mempertimbangkan faktor kenyamanan pengguna desain tersebut.

Penerapan konsep/aturan umum Feng Shui lebih banyak terpaku pada angka dan simbol arti terlihat, terutama pada desain tangga pada umumnya. Kenyamanan ataupun keamanan adalah nomor terakhir formula dianggap lebih penting. Penerapan teori bentuk yang pada umumnya digunakan untuk penentuan warna melupakan nuansa ruang hasil desain akhir yang meskipun benar penggunaan warna tertentu menurut formula, ruangan tersebut tidak nyaman dipakai, misalnya akibat tone warna yang terlalu kuat. Penerapan teori Kompas yang umumnya digunakan para praktisi Feng Shui tanpa mempertimbangkan bentuk desain akhir akan berimbas langsung pada penggunanya, misalnya arah hadap pintu masuk utama yang dibuat tidak sejajar jalan di depannya benar menurut formula, tetapi hasilnya pintu tersebut menghadap ke dinding pembatas tetangga ataupun tidak terselesaikan dengan baik sehingga desain tampak muka terlihat aneh. Penerapan teori Bintang bergerak yang belakangan ini mulai lazim digunakan, misalnya posisi $\mathrm{KM} / \mathrm{WC}$ yang benar menurut formula, tetapi posisi tersebut tidak memungkinkan adanya bukaan keluar untuk penghawaan alami. Jika dipelajari lebih lanjut, dapat diketahui bahwa penerapan formula apapun dapat diselesaikan secara fisik dan lebih logis tanpa menyalahi aturan dasar Feng Shui. Asumsi "asal ada" koreksi Feng Shui dengan memasang benda-benda pengaktif bintang baik terutama demi kemakmuran menurut teori Bintang Bergerak tanpa memikirkan proporsi juga akan kurang efektif. Semua yang dilakukan menurut teori dan metode Feng Shui perlu dilakukan secara proporsional.

Bentuk (form) dan formula tidak dapat dipisahkan dalam penerapan teori Feng Shui. Dalam Feng Shui, relasi antara keduanya termasuk dekat dan saling mengisi. Tinggal bagaimana para desainer/arsitek beserta para praktisi memecahkan masalah pada masing-masing kasus.

\section{GLOSARI}

1. Tone warna: kekuatan warna. Tone warna mencolok mata disebut tinggi, tone warna lembut disebut tone rendah.

2. Air datang: aliran air / arus lalu lintas sebagai pengganti air yang mengarah ke bangunan yang dituju. Aliran air datang dianggap sebagai aliran yang baik karena membawa kemakmuran (air) dan keberuntungan.

3. Air pergi : aliran air / arus lalu lintas sebagai pengganti air yang meninggalkan bangunan. Aliran air pergi dianggap sebagai aliran yang kurang baik karena dapat membawa pergi kemakmuran dan keberuntungan.

4. Timely: angka yang dianggap baik pada periode Feng Shui yang sedang berlangsung. Tahun 2015 ini termasuk periode 8 , maka angka 8, 9, dan 1 dianggap baik.

5. Untimely: angka yang dianggap out of period dari periode Feng Shui yang sedang berlangsung. Angka 7 pada periode 7 dianggap baik, tetapi di periode 8 termasuk kurang baik.

6. Mountain star: bintang gunung, dalam penulisan $9 * 2 * 7$, bintang gunung adalah 9 . Bintang gunung yang baik biasa digunakan untuk sektor ruang tidur.

7. Water star: bintang air, dalam penulisan $2 * 5 * 8$, bintang air adalah 8 . Bintang air yang baik biasanya digunakan untuk area aktivitas dan dianjurkan untuk diaktifkan dengan water features (kolam ikan, air terjun atau air mancur).

\section{DAFTAR PUSTAKA}

Atherton, Gahle, (2000). The Real Feng Shui Guide: The Perfect Arrangement, Simple Secrets Unveiled. Malaysia: Synergy Books International.

He, Xiao Xin \& Luo Juan. (2007). 中国风水史, Beijing: Jiu Zhou Press.

Inajati. (2005). "Kota Gede: an archaeological perspective of a capital City in Java in the $17^{\text {th }}$ century" dalam Jurnal Humaniora Volume 17, Nomor 2, Juni 2005, hlm. 125-134.

Kehardtum, Mas. (2011). Advanced City Landforms. Bangkok: International Feng Shui Academy.

Koh, Vincent. (2003). Basic Science of Feng Shui. Singapura: Asiapac Publication.

Lip, Evelyn. (2004). Feng Shui: a Layman's Guide. Singapura: Times Editions Pte Ltd.

Lo, Raymond. (2005). Feng Shui Essentials. Hongkong: Feng Shui Lo.

Lituhayu, Cahaya. (2012). "Pengaruh Warna terhadap Psikologi Pengguna dalam Perancangan Fasilitas Bedah Plastik Estetik" dalam Jurnal S1 FSRD ITB No. 61, hlm. 58-65. 
Neufert, Ernst \& Peter. (2012). Architects'Data. UK: Blackwell Publishing.

Yan, Ting Zhen \& Sun Lu Jian. (2012). 中國風水文 化. Hongkong: Joint Publishing (HK) Co.
Ltd.

Yap, Joey. (2006). Feng Shui for Homebuyers- Exterior. Kualalumpur: Mastery Academy of Chinese Metaphysics Sdn. Bhd. 